\title{
Entrelacs
}

Cinéma et audiovisuel

Hors-série $n^{\circ} 4$ | 2016

Paysages en séries

\section{Paysages urbains}

\section{Maylis Asté et Marie Maillos}

\section{OpenEdition}

Journals

Édition électronique

URL : http://journals.openedition.org/entrelacs/4419

DOI : 10.4000/entrelacs.4419

ISBN : $2261-5482$

ISSN : 2261-5482

Éditeur

Éditions Téraèdre

Édition imprimée

Date de publication : 1 novembre 2016

ISSN : 1266-7188

\section{Référence électronique}

Maylis Asté et Marie Maillos, «Paysages urbains », Entrelacs [En ligne], Hors-série n 4 | 2016, mis en ligne le 07 février 2019, consulté le 24 septembre 2020. URL : http://journals.openedition.org/ entrelacs/4419; DOI : https://doi.org/10.4000/entrelacs.4419

Ce document a été généré automatiquement le 24 septembre 2020.

Tous droits réservés 


\title{
Paysages urbains
}

\author{
Maylis Asté et Marie Maillos
}

1 Le paysage s'observe, se contemple et s'analyse mais parfois, aussi, se construit. Les paysages urbains particulièrement se bâtissent et se montrent dans un mouvement constant de balancier entre la conception de la ville - au sens de construction, de pensée préalable - et la conception de la ville - cette fois au sens de réception, d'imaginaire. Le paysage urbain ne cesse ainsi ses allers et retours entre architectes et géographes.

2 La série télévisée trouve se place au cœur de ce balancier. Si elle permet une représentation quasi-documentaire des zones urbaines - dont on verra qu'elle n'est jamais exempte de subjectivité - elle est aussi un art populaire, ce qui lui permet d'absorber, de commenter et de créer les imaginaires de la ville. C'est le cas par exemple de la série Gomorra, qui s'appuie sur un imaginaire de l'Italie mafieuse d'ores et déjà bien ancré pour en proposer un nouveau, contemporain, qui influe lui-même sur la construction de la ville parthénopéenne.

3 En sus de ce balancier de la ville pensée à la ville perçue et vice-versa, vient se greffer un autre mouvement dans la représentation de la ville: celui entre généralisation et particularité culturelle. Une ville comme Vancouver peut ainsi, en dépit de ses particularités esthétiques et culturelles ou grâce à elles, devenir un schéma de réception pour des villes, voire pour toute ville tandis que, à l'inverse, ces villes forment, à elles toutes, le plan de construction d'une ville idéelle, normalisée, culturellement " harmonisée » telles que celles qui passent sur nos écrans presque sans se faire voir.

4 Par ces balanciers constants le paysage urbain devient un paysage dont l'histoire est mouvementée, les transformations parfois radicales, et qui est en cela hautement figuratif de l'espèce qui l'habite. 